\title{
Competition of Fairs on the Basis of the Composition Distribution ${ }^{2}$
}

\author{
Article history: \\ Received: 25 February 2017 \\ Sent for revision: 28 March 2017 \\ Received in revised form: 16 May 2017 \\ Accepted: 21 July 2017 \\ Available online: 10 October 2017
}

\begin{abstract}
Optimization of competitiveness is one of basic elements of modern trade show marketing. The importance of competitiveness rapidly increases in last time. The goal of this work is finding recipes for optimization of competitiveness using analogies with natural nano processes. Here will be used analogy with Boltzmann's distribution of particles on energy levels. The main difference consists in generalization of subjects of distribution. In Boltzmann's theory, particles and energies are the basic subjects. Here we will be use terms "services" and "price of the service". The terms "services" and "price" have to be accepted in most general case. Due to the analogy with Boltzmann's distribution, the distributions "services" - "price" are of exponential type with different parameters. Since the parameters of distributions can be different average values must be determined by means of resulting distribution, which is called composition. On the example of resulting distribution for two exponential distribution densities was concluded that average values, calculated over resulting distribution, are higher when parameters are close. This conclusion must be tested for the case of higher number of distributions.
\end{abstract}

Key words: fair competitiveness, Boltzmann's distribution, composition of function, Dirichlet's formula

\section{Konkurentnost sajmova na osnovu kompozicije raspodela}

Apstrakt: Optimizacija konkurentnosti predstavlja jedan od osnovnih elemenata savremenog sajamskog marketinga, pri čemu značaj

\footnotetext{
1 JKP "Tržnica", Novi Sad, ekonomistdoo@sbb.rs

2 This paper is result of research on PhD thesis and it is adopted to standards of "Industrija“
} 
Prdić N.: Competition of Fairs on the Basis of the Composition Distribution

konkurentnosti dobija sve veću težinu. Cilj ovog rada je da se putem analogija marketinških procesa u ekonomiji sa nano-procesima u prirodi pronađe model za optimizaciju konkurentnosti. Korišćena je analogija sa Bolcmanovom statističkom raspodelom čestica po energijama, pri čemu su Bolcmanovi termini čestice $i$ energije zamenjeni terminima "količina prodate usluge" $i$ „cena usluge“. Termin „usluga“ $i$ "cena" treba shvatiti u najopštijem smislu. Zbog analogije sa Bolcmanovom raspodelom, raspodele "usluga-cena“ su eksponencijalnog tipa sa različitim parametrima. Zbog različitosti parametara srednje vrednosti se moraju računati po rezultujućoj raspodeli koja se naziva kompozicija. Na primeru rezultirajuće raspodele za dve eksponencijalne gustine raspodele zaključeno je da srednje vrednosti računate po rezultirajućoj raspodeli rastu kada su parametri bliski jedan drugom. Ovaj zaključak svakako treba proveriti na slučajevima većeg broja raspodela.

Ključne reči: konkurentnost sajmova, Bolcmanova raspodela, kompozicija funkcija, Dirihleova formula

\section{Introduction}

Gathering of data for two fairs in Munich (BAUMA) and in Bologna (SAIE), pointed out assuredly that distribution determining competitiveness are of exponential type. This was reason for the use of analogy between marketing processes and physical processes defined by Boltzman's distribution. The set of marketing problems is noticeably withered than Boltzman's problem dealing with distribution articles and energy levels. In marketing processes, very different concepts can be described by statistical dependence. Based on this idea with help of corresponding mathematical modeling was developed system for advancing of competitiveness. This advancing achieved by means of resulting distribution that is called composition, changing parameters of composition components within increase competitiveness.

More than 1500 years fairs were the primary mechanism of commodity-money exchange. (Chapman, 1995) The fair marks the indoor and outdoor space where the regular and irregular periods concentrate supply and demand of goods and services. (Vračar, 1996) In the new economy characterized by global competitiveness, knowledge and creativity, we need a new approach to the fair as a marketing instrument of communication. In order for a company maintain or improve its position in the market, the fair has to utilize and maximize all the resources that are available to him, as well as to create an atmosphere in which top quality presentations and innovations become the mode. (Prdić, 2010) "Matter of the efficiency of performing at the fair as an instrument of sales improvement can be observed through the prism of achieving individual, specific, economic and communication objectives. Therefore, efficiency is the ability to achieve the set goal. It follows that what 
Prdić N.: Competition of Fairs on the Basis of the Composition Distribution

is efficient enterprise is the one which by performance at the fair achieved its objectives." (Prdić, 2012)

The maximum effect is achieved by planning personal sales, commercial ads, appearances at fairs and other promotional activities as well as integrated marketing campaigns. (Wilmshurts, 1991)

One of the very important elements of the strategic development of trade and price determination and coordination of services, including the price of exhibition space. Comparing the cost of space with those of other trade is beneficial because these costs are taken even more than $20 \%$ of the total cost of performing at the fair. (Zarić, 1999)

Obtaining advantages with respect competitors in fair marketing and their increasing is one of main problems of modern fair marketing. The aim is to prove hypothesis of fair competitiveness based on allocation composition using certain regularity. We shall try here to find way to increase competitiveness in fair marketing using Boltzmann's figure terms: number of particles and energies of particles (Hill, 1956; Tošić, 1978). In analysis of competitiveness will be used concepts "services" and "price". These marketing terms could be very wide and general (from material services to the intellectual one).

Competitiveness is a combination of the best methods and models of market business, where consumer, buyer or some other interested market subjects, finds common goals as a company, and buys certain products or services for satisfaction and benefits in communication acceptable way. Indicator of competitiveness may be recognized by acceptable prices and good quality of goods and services. If we want to compare competitiveness of two fairs, which may be important for election of certain fair within marketing communication strategy of a company, it is necessary to gather quantitative data that are important and valuable parameters for the company that has to make decision and choose between two competitive fairs.

\section{Theory}

\subsection{Boltzmann's Statistic}

We shall consider fair marketing organization, which possesses $n 1$ services of the type 1, n2 services of the type 2, etc. up to $\mathrm{nM}$ services of the type M. The price of the service of type 1 will be denoted with $C_{1}$, the price of the service of type 2 with $\mathrm{C}_{2}$ etc.

Using analogy with statistical physics, we include statistical probability as a measure of probability of sold services. The laws of conservation of services 
Prdić N.: Competition of Fairs on the Basis of the Composition Distribution

and laws of conservation of profit will be also used in formulating of the statistics. The most probable distribution of services over prices will be obtained by minimization of the function

$$
\Phi=\ln P-\alpha n-\beta Q
$$

which represents analogy of thermo dynamical potential (Zubarev, 1971). In formula (1) $P$ is statistical probability which is given by

$$
P=\frac{n !}{\prod_{i=1}^{M} n_{i}} \approx \frac{n^{n}}{\prod_{i=1}^{M} n_{i}{ }^{n i}}
$$

where $n=\sum_{i=1}^{M} n_{i}=$ const. is total number of services, while $Q=\sum_{i=1}^{M} C_{i} n_{i}=$ const. is profit.

Taking into account given expressions the function $\Phi$ becomes:

$$
\Phi=n \ln n-\sum_{i=1}^{M}\left(n_{i} \ln n_{i}+\alpha n_{i}+\beta C_{i} n_{i}\right)
$$

where $\alpha$ and $\beta$ are undetermined constants.

Taking variation $\delta \Phi$ equal to zero, we come to the law of most probable distribution

$$
n_{i}=e^{(\alpha+1)} e^{\beta C}
$$

Inserting (4) in the expression for total number of services we obtain the final formula for more probable distribution:

$$
n_{i}=n \frac{e^{-\beta C_{i}}}{\sum_{i=1}^{M} e^{-\beta C_{i}}}
$$

The probability to $n_{i}$ services be sold with price $C_{i}$ follows from (5) and it is given by formula: 
Prdić N.: Competition of Fairs on the Basis of the Composition Distribution

$$
W_{i}=\frac{n_{i}}{n}=\frac{e^{-\beta C_{i}}}{\sum_{i=1}^{M} e^{-\beta C_{i}}}
$$

Discrete representation of probability is complicate for calculations and therefore it will be written in continual approximation (discrete variable $C_{i}$ goes over to continual variable $\mathrm{C}$, while sum in respect of discrete index 'i' goes over to integral from 0 to $\infty$ with respect to continual variable $\mathrm{C}$ ):

$$
W \rightarrow \frac{e^{-\beta C}}{\int_{0}^{\infty} d C e^{-\beta C}}=\beta e^{-\beta C}
$$

The formula (7) represents distribution density of random variables $C_{1}, C_{2}$ etc.

\subsection{Composition Of Two Or More Distributions}

If we have set of distributions of the same type but with different parameters $\beta$ than average characteristics of such system can be calculated by means of resulting distribution. (Cap, 2003)

For two distributions with densities $\rho_{1}$ and $\rho_{2}$ resulting composition is given by:

$$
C_{2}(x)=\int_{0}^{\infty} d y \rho_{1}(x-y) \rho_{2}(y)
$$

On the basis of these expressions the formula of composition of $\mathrm{m}$ distributions is given by:

$$
C_{m}(x)=\int_{0}^{\infty} d y \rho m(x-y) C_{m-1}(y)
$$

Resulting distribution given in integral form (9) leads in application to complicated mathematical expresions. It is the reason to translate this integral formula into algebraic form. The formula (9), multiplied with $e^{-k x}$, integrates with respect to $\mathrm{x}$ from 0 to $\infty$.

Using Dirichlet's formula (Smirnov, 1958) we translate (9) into

$$
C_{m}(k)=\rho_{m}(k) C_{m-1}(k) m=1,2 \ldots N
$$


where $C_{m}(k)$ and $\rho_{m}(k)$ are Laplace's images the function $C_{m}(x)$ and $\rho_{m}(x)$. Iterating formula (8), we obtain the Laplace's image of the composition of $\mathrm{N}$ distributions:

$$
C_{m}(k)=\prod_{s=1}^{N} \rho_{s}(k)
$$

By means of inverse Laplace's transformation, $f(x)=\frac{1}{2 \pi} \int_{C_{n-i \infty}}^{C_{n+i \infty}} d k e^{k x} f(k)$ we find the following expression for the composition $\mathrm{C}_{\mathrm{N}}(\mathrm{x})$

$$
C_{N}(x)=\frac{1}{2 \pi i} \int_{C_{n-i \infty}}^{C_{n+i \infty}} d k e^{k x} \prod_{s=1}^{N} \rho_{s}(k)
$$

Formula (10) becomes relative simple for the case of exponential distribution, since the Laplace's image of exponential function is:

$$
\rho(k)=\int_{0}^{\infty} d x e^{k x} \rho(x)=a \int_{0}^{\infty} d x e^{(k+a) x}=\frac{a}{a+k}
$$

Based on formulas (9) and (11) we obtain the expression:

$$
C_{N}(x)=\frac{1}{2 \pi i} \int_{C_{n-i \infty}}^{C_{n+i \infty}} d k e^{k x} \prod_{s=1}^{N} \frac{a_{s}}{a_{s}+k}
$$

The function, which integrates in complex $\mathrm{k}$ plane, has simple poles, so that on the basis of theorem of residuum [Hill, 1956] relatively simply we get

$$
C_{N}(x)=\left[\begin{array}{l}
\frac{e^{-a 1 x}}{\left(a_{2}-a_{1}\right)\left(a_{3}-a_{1}\right) \ldots\left(a_{N}-a_{1}\right)}+ \\
+\frac{e^{-a_{22} x}}{\left(a_{1}-a_{2}\right)\left(a_{3}-a_{2}\right) \ldots\left(a_{N}-a_{2}\right)}+\ldots \\
\ldots+\frac{e^{-a N C}}{\left(a_{N}-a_{1}\right)\left(a_{N}-a_{2}\right) \ldots\left(a_{N-1}-a_{N}\right)}
\end{array}\right] \prod_{s=1}^{N} a_{s}
$$

The obtained formula is valid for set of random variables $X_{1}, X_{2} \ldots$ for which the distribution parameters are $a_{1}, a_{2} \ldots$

In the case when we consider distribution of "services" over "prices" in formula (15) $X \rightarrow C$ i $a_{i} \rightarrow \beta_{i}$

Independently on the number of exponential distributions which form composition, the composition always represents bell, positive definite curve 
Prdić N.: Competition of Fairs on the Basis of the Composition Distribution

which tends to zero when $\mathrm{C} \rightarrow 0$ and $\mathrm{C} \rightarrow \infty$. The curve has one maximum at the point $C_{M}$ and one inflection point at $C_{P}$. The abscise of inflection point is always higher than the abscise of maximum point $\left(C_{p}>C_{M}\right)$.

\subsection{Optimization Of Competitiveness}

Taking into account of up to now exposed it is obvious that by means of resulting distribution, i.e. composition, can be done optimization of competitiveness. In order to justify this we shall consider the composition of two distributions, since in this case all relevant results can be obtained analytical. In accordance with the general formula (15) composition of two distributions is given by:

$$
R_{2}(C)=\frac{\beta_{1} \beta_{2}}{\beta_{1}-\beta_{2}}\left(e^{-\beta_{2} C}-e^{-\beta_{1} C}\right)
$$

This formula has maximum at the point $\mathrm{C}_{\mathrm{M}}$

$$
C_{M}=\frac{\ln \beta_{2} / \beta_{1}}{\beta_{2}-\beta_{1}}
$$

and inflection point at the point $\mathrm{C}_{\mathrm{P}}$

$$
C_{P}=2 C_{M}=2 \frac{\ln \beta_{2} / \beta_{1}}{\beta_{2}-\beta_{1}}
$$

The formula (16) will be analyzed in two different cases.

In the first case $\beta_{1} \rightarrow \beta_{2}$. Using the L'Hospital theorem, we get the formula

$$
\underset{\beta 1 \rightarrow \beta_{2}}{R_{2}}=\beta_{2} e^{-\beta_{2} C} \beta_{2} C
$$

In second case we take $\beta_{1} \gg>\beta_{2}$. Then approximately follows that

$$
\underset{\beta 1 \square \beta_{2}}{R_{2}}=\beta_{1} e^{-\beta_{2} C}
$$

From these results, it is seen that by closing of distribution parameters we increase

distribution density, while the splitting of parameters we decrease distribution density, 
Prdić N.: Competition of Fairs on the Basis of the Composition Distribution

since

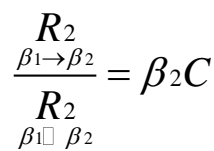

This conclusion can be translated to the case of composition of set of distributions. It is

expectable that closing of parameters leads to the increase of averages, while the splitting

leads to the decrease

\section{Results}

For researches of competitiveness of fairs as market institutions, it is necessary to gather certain data which are official data of particular fairs, to be able to determine optimal competitiveness of these fairs. These data are prerequisite for research of competitiveness between two fairs. Data may be gathered from a company that wants to know which fair offers better condition for company's goals. Some sources and information may be also obtained from independent research agencies and fair industry associations.

Based on the used model we can quote the stages of determining of competitiveness and can determine how competitiveness can be advanced.

For some fairs we aggregate data about acting a set of marketing services.

The obtained statistical data (if their histograms are exponentially like) can be translated into analytical curve by means of minimal square method. So we obtained that distribution densities based on the formula of resulting distribution can be found. The parameters of found curves can be arranged so to lead to better competitiveness. It was pointed out earlier that closing of parameters (the increase of density of set of parameters) leads to the increase of respectable values (average values). This closing of parameters is independent problem that requires detail analyses.

The changing of values of parameters can be achieved by advancing methods of servicing, by more intensive advertising and by application of new and original approaches of services.

Statistical data concerning transfer of services are gathered over two fairs. These data, in very high percent, show that the transfer services are of exponential type. It was reason to estimate competitiveness fairs on the basis of analogy with Boltzman's statistic (Hill, 1956; Tošić, 1978). It means that 
"services" and "prices" will be connected by means of exponential functions. If prices are considered as continual variables the densities of distribution of random variables are given by the formula:

$$
\rho(C)=\beta e^{-\beta C}
$$

Statistical data enable us to determine histograms where ni is number of $-\mathrm{i}$ type services, while $C_{i}$ is the price of $-I$ services.

Using the minimal squares method we can obtain from histograms the analytical functions

$$
n=n_{0} e^{-\beta C}
$$

The function (22) has to be normalized to unite in the interval $C \in[0, \infty]$.

Marketing operations can be of differente type but all of them must have distribution density of exponential type (21). For sets of marketing operations of differrente type all distribution densities are of the type (21), but with differente parameters. The calculation of relevant characteristics for the set of marketing operations must be found composition of density distributions for all operations [Cap, 2003; Hewitt, 2006).

The resulting distribution for $n$ marketing operations is given by the formula:

$$
R_{N}(C)=\left[\begin{array}{l}
\frac{e^{-\beta_{1} C}}{\left(\beta_{2}-\beta_{1}\right)\left(\beta_{3}-\beta_{1}\right) \ldots\left(\beta_{N}-\beta_{1}\right)}+ \\
+\frac{e^{-\beta_{2} C}}{\left(\beta_{1}-\beta_{2}\right)\left(\beta_{3}-\beta_{2}\right) \ldots\left(\beta_{N}-\beta_{2}\right)}+\ldots \\
\cdots+\frac{e^{-\beta_{N} C}}{\left(\beta_{N}-\beta_{1}\right)\left(\beta_{N}-\beta_{1}\right) \ldots\left(\beta_{N-1}-\beta_{1}\right)}
\end{array}\right] \prod_{s=1}^{N} \beta_{s}
$$

The most natural estimate of competitiveness can be done with help of mathematical expectation over resulting distribution $R_{N}(C)$. Formula (23) requires complicated calculations and therefore the function $R_{N}(C)$ will be substituted by simulation function which is positive definite, which tends to zero when $\mathrm{C} \rightarrow 0$ and $\mathrm{C} \rightarrow \infty$, whose maximum is in $\mathrm{C}_{M}$ and inflaction point is at $C_{p}$. The inflaction point for every function of type (23) is higher then apscise of maxinun $C_{M}$. It can be easily shown that simulation function for $R_{N}(C)$ is of following form: 
Prdić N.: Competition of Fairs on the Basis of the Composition Distribution

$$
\begin{aligned}
& R_{N}(C) \approx \mathcal{N} C^{\left(\frac{C M}{C P-C M}\right)^{2}} e^{-\frac{C}{C M}\left(\frac{C M}{C P-C M}\right)^{2}} \approx \mathcal{N} C^{r} e^{-\frac{r}{C M} C} \\
& r=\left(\frac{C_{M}}{C_{P}-C_{M}}\right)^{2}
\end{aligned}
$$

Normalized in intervale $C \in[0, \infty]$ has the form:

$$
R_{N}(C)=\frac{1}{\Gamma(r+1)}\left(\frac{r}{C_{M}}\right)^{r+1} C^{r} e^{-\frac{r}{C_{M}} C}
$$

The use of these function is very effective in shortening of calculations, which requires the use of the function (23). Competitiveness, as it was said earlier, will be estimated by means of average price:

$$
\langle C\rangle=\int_{0}^{\infty} d C C R_{N}(C)=\frac{r+1}{r} C_{M}
$$

In the next section the Fair I, as well as Fair II, will be taken as statistical samples.

\subsection{Comparing Competitiveness}

The competitiveness will be compared to on the basis of following marketing operations: rental of indoor and outdoor exhibition space by categories based on the quality of space. Data were determined on the basis of mean values of different price categories depending on space surface rented during the last 5 years for two representative trade fair in Munich (AUMA) denoted as Fair I, and Bologna (SAIE) denoted as Fair II. For quoted operations we obtained the following tables (1-12) of data. In tables are involved "prices" and number of "services" units.

Using six tables concerned with Fair I, we determined the composition in accordance with formula (3). The same was done for six sets of data concerned with Fair II. The points $C_{M}$ and $C_{P}$ are found and they were used for finding of simulation function given by formula (25). $\langle\mathrm{C}>$ । calculated with help of the function (25) was 80.09 euro per $\mathrm{m}^{2}$. Mean price for Fair II was $\langle C\rangle_{\|}=94.91$ euro per $\mathrm{m}^{2}$. The results obtained in described way show that competetiveness of Fair II is higher than competitiveness of Fair I. 
Prdić N.: Competition of Fairs on the Basis of the Composition Distribution

\section{Discussion}

In order to test correctness of theory we changed values of parameters $\beta$ for both analysed fairs.

Really existing set of parameters for Fair I $\beta_{1}=0.060, \beta_{2}=0.066, \beta_{3}=0.076$, $\beta_{4}=0.078, \beta_{5}=0.079$ and $\beta_{6}=0.100$ was substituted by the set of parameters whose differences were less than those of the real set. This set of parameters was $\beta_{1}=0.070, \beta_{2}=0.072, \beta_{3}=0.075, \beta_{4}=0.076, \beta_{5}=0.077$ and $\beta_{6}=0.080$. For this new set of parameters the mean price was $\left\langle C>_{1}=80.12\right.$ euro per $\mathrm{m}^{2}$. It is sign that closing of parameters leads to the higher values of average price. After this we considered the set of parameters $\beta_{1}=0.051, \beta_{2}=0.060, \beta_{3}=0.074$, $\beta_{4}=0.085, \beta_{5}=0.100$ and $\beta_{6}=0.150$. It is sign that differences between parameters are higher than in real set of parameters. For this choice of parameters was obtained the average price $\langle\mathrm{C}\rangle_{1}=76.83$ euro per $\mathrm{m}^{2}$.

If we take for Fair II the set of parameters $\beta_{1}=0.051, \beta_{2}=0.053, \beta_{3}=0.056$, $\beta_{4}=0.062, \beta_{5}=0.068$ and $\beta_{6}=0.073$ whose density is higher than the density of the real set $\left(\beta_{1}=0.047, \beta_{2}=0.050, \beta_{3}=0.055, \beta_{4}=0.072, \beta_{5}=0.081\right.$ and $\left.\beta_{6}=0.097\right)$ we obtain $\langle\mathrm{C}\rangle_{\|}=100.59$ euro per $\mathrm{m}^{2}$. This value is higher than real price $\langle\mathrm{C}\rangle_{\|}$. Finally, introducing the set of parameters having higher differenes than the real one: $\beta_{1}=0.045, \beta_{2}=0.058, \beta_{3}=0.087, \beta_{4}=0.098, \beta_{5}=0.120$ and $\beta_{6}=0.140$ we calculated average price $\langle C\rangle_{\|}=74.16$ euro per $\mathrm{m}^{2}$. This justifies heading hypothesis for Fair II, too.

It is necessary to mention that competitiveness of fairs is the assumption which results in company's estimation in which fair it may fulfill its plans and goals. Is the price of exhibition space the most important, and that is the subject of our research, or some other value or communication indications which show that company's goals will be obtained by its presence in certain fair.

\section{Conclusion}

The analyses done with really existing data has shown that closing of parameters increases competitiveness. The spliting of parameters decreases competitiveness (Pfeffer \& Nir, 2000). It should be pointed out that closing as well as spliting of parameters is quite independence problem which requires other independence approaches.

The hypothesis that strategic approach to fairs results in increased business efficiency and competitiveness of the two relevant international fairs. The used method is method of competitiveness based on allocation composition, and this is the base for a company to choose a fair that would help it to obtain 
Prdić N.: Competition of Fairs on the Basis of the Composition Distribution

its goals. It is necessary to mention that in some previous researches this author has made analysis of product selling and its economic and communication effects of participation in fair exhibitions.

"The results of the research show that the trade fairs are the effcient instrument of salesimprovement and that we can, up to some point, influence the level of interest of the buyersand the decision making on purchase. Certain papers and studies (like Ballesteret al., 2008), give a hint that the wine experts (including winemakers) would perform better in a role of assessing the attributes of wine and its quality than the new consumers." (Prdić, Kuzman, Barjaktarović, 2014)

Aforementioned theory gives the possibility of the wide spectrum of application on showed examples of competition of fairs as well as on different measurement of competitiveness.

These researches present solid bases and recommendation for future researches, both theoretical and empiric, which would present the value of this optimization model in practice, and also make comparison on the bases of certain statistic and other methods usable in practice that, may show some regularity in communication process between a company and its target market.

\section{References}

Cap F. F. (2003). Mathematical Methods in Physics and Engineering with Mathematica. USA: Chapman\&Hall/CRC

Chapman, E. A. (1995). Exhibit Marketing. USA, Maidenhead: McGraw-Hill.

Hewitt P. G. (2006). Conceptual Physics, San Francisco. New York, USA: PearsonAddison Wesley.

Hill T. L. (1956). Statistical Mechanics (Principles and Selected Applications). New York-Toronto-London: McGraw-Hill Company Inc.

Pfeffer J. I., S. Nir. (2000). Modern Physics. London, Singapore: Imperial College Press.

Prdić, N. (2010). Sajmovi građevinarstva - Instrument marketing komuniciranja. (Unpublished master's thesis), University of Novi Sad, Subotica, Serbia.

Prdić, N. (2012). Efekti nastupa preduzeća na sajmu, Anali ekonomskog fakulteta $u$ Subotici. 48 (28), 133-143.

Prdić, N., Kuzman, B., Barjaktarović, M. (2014): Practical Research Results of a Successful Company's Appearance at the Fai. Ekonomika poljoprivrede, 61(4), 903-914.

Smirnov V. I. (1958). Kurs vysšej matematiki. 2 (16 ${ }^{\text {th }}$ ed.), Moskva, Russia: Gosizdat.

Tošić B. (1978). Statistička fizika, Novi Sad, Serbia: Prirodno-matematički fakultet, Institut za fiziku.

Vračar, D. (1996). Strategije tržišnog komuniciranja. Serbia, Belgrade: Privredne vesti "Europublic" Belgrade. 
Prdić N.: Competition of Fairs on the Basis of the Composition Distribution

Wilmshurts, J. (1991). The Fundamentals and Practice of Marketing. ( $2^{\text {nd }}$ ed.), Heinemann: Butterworth.

Zarić, S. (1999). Čarobni svet sajmova, Serbia, Belgrade: Grmeč.

Zubarev D. N. (1971). Neravnovesnaja statističeskaja termodinamika, Russia, Moskva: Nauka

Retrieved from www.bauma.de (31.12.2011)

Retrieved from www.saie.bolognafierefiere.it (31.12.2011) 
Prdić N.: Competition of Fairs on the Basis of the Composition Distribution

\section{Appendix}

Table 1: Price of leased space in category A depending on the surface for Fair $\mathrm{n}_{0}=10000$ $\beta=0.060$

\begin{tabular}{ccccc}
\hline $\mathbf{C}_{\mathbf{i}}\left(\mathbf{E U R} / \mathbf{m}^{2}\right)$ & 73.8 & 81.5 & 94.2 & 108.4 \\
$n_{i}$ & 1200 & 750 & 350 & 150 \\
\hline
\end{tabular}

Source: www.bauma.de (31.12.2011)

Table 2: Price of leased space in category B depending on the surface for Fair I $\mathrm{n}_{0}=200000$ $\beta=0.076$

\begin{tabular}{ccccc}
\hline $\mathbf{C}_{\mathbf{i}}\left(\mathrm{EUR} / \mathbf{m}^{2}\right)$ & 68.5 & 74.4 & 85.6 & 91.0 \\
$n_{i}$ & 1100 & 700 & 300 & 200 \\
\hline
\end{tabular}

Source: www.bauma.de (31.12.2011)

Table 3: Price of leased space in category $\mathrm{C}$ depending on the surface for Fair I

\begin{tabular}{ccccc}
$\mathrm{n}_{0}=1000000000$ & $\beta=0.066$ \\
\hline $\mathbf{C}_{\mathbf{i}}\left(\mathrm{EUR} / \mathbf{m}^{2}\right)$ & 215.8 & 223.2 & 227.6 & 244.0 \\
$n_{i}$ & 700 & 400 & 300 & 100
\end{tabular}

Source: www.bauma.de $(31.12 .2011)$

Table 4: Price of leased space in category $D$ depending on the surface for Fair I

\begin{tabular}{ccccc}
$\mathrm{n}_{0}=1500000000$ & $\beta=0.079$ \\
\hline $\mathbf{C}_{\mathbf{i}}\left(\mathrm{EUR} / \mathbf{m}^{2}\right)$ & 185.1 & 191.9 & 195.7 & 212.0 \\
$n_{i}$ & 720 & 390 & 290 & 80 \\
\hline
\end{tabular}

Source: www.bauma.de (31.12.2011)

Table 5: Price of leased space in category $E$ depending on the surface for Fair I

\begin{tabular}{ccccc}
$\mathrm{n}_{0}=300000000$ & $\beta=0.078$ & & \\
\hline $\mathbf{C}_{\mathbf{i}}\left(\mathrm{EUR} / \mathbf{m}^{2}\right)$ & 165.2 & 173.1 & 177 & 189 \\
$n_{i}$ & 730 & 410 & 300 & 120
\end{tabular}

Source: www.bauma.de $(31.12 .2011)$

Table 6: Price of leased space in category F depending on the surface for Fair I

\begin{tabular}{ccccc}
$\mathrm{n}_{0}=100000000000$ & \multicolumn{5}{c}{$\beta=0.100$} \\
\hline $\mathbf{C}_{\mathbf{i}}\left(\mathrm{EUR} / \mathbf{m}^{2}\right)$ & 185.1 & 194 & 200.3 & 212.4 \\
$n_{i}$ & 900 & 380 & 200 & 60 \\
\hline
\end{tabular}

Source: www.bauma.de (31.12.2011) 
Prdić N.: Competition of Fairs on the Basis of the Composition Distribution

Table 7: Price of leased space in category A depending on the surface for Fair II $\mathrm{n}_{0}=30000$ $\beta=0.050$

\begin{tabular}{ccccc}
\hline $\mathrm{C}_{\mathbf{i}}\left(\mathrm{EUR} / \mathbf{m}^{2}\right)$ & 68 & 73.8 & 84.0 & 114.1 \\
$n_{i}$ & 1000 & 750 & 450 & 100 \\
\hline
\end{tabular}

Source: www.saie.bolognafierefiere.ti $(31.12 .2011)$

Table 8: Price of leased space in category B depending on the surface for Fair II $\mathrm{n}_{0}=500000$ $\beta=0.047$

\begin{tabular}{ccccc}
\hline $\mathbf{C}_{\mathbf{i}}\left(\mathrm{EUR} / \mathbf{m}^{2}\right)$ & 125.1 & 133.5 & 144.9 & 177.3 \\
$n_{i}$ & 1400 & 940 & 550 & 120 \\
\hline
\end{tabular}

Source: www.saie.bolognafierefiere.ti $(31.12 .2011)$

Table 9: Price of leased space in category $C$ depending on the surface for Fair II $\mathrm{n}_{0}=50000000$ $\beta=0.055$

\begin{tabular}{ccccc}
\hline $\mathbf{C}_{\mathbf{i}}\left(\mathrm{EUR} / \mathbf{m}^{2}\right)$ & 189.4 & 196.7 & 206 & 219.9 \\
$n_{i}$ & 1500 & 1000 & 600 & 280 \\
\hline
\end{tabular}

Source: www.saie.bolognafierefiere.it $(31.12 .2011)$

Table 10: Price of leased space in category $D$ depending on the surface for Fair II $\mathrm{n}_{0}=90000$ $\beta=0.072$

\begin{tabular}{ccccc}
\hline $\mathbf{C}_{\mathbf{i}}\left(\mathrm{EUR} / \mathbf{m}^{2}\right)$ & 64.8 & 69.6 & 77.1 & 88.8 \\
$n_{i}$ & 850 & 600 & 350 & 150 \\
\hline
\end{tabular}

Source: www.saie.bolognafierefiere.it $(31.12 .2011)$

Table 11: Price of leased space in category E depending on the surface for Fair II $\mathrm{n}_{0}=14000000$ $\beta=0.081$

\begin{tabular}{ccccc}
\hline $\mathbf{C}_{\mathbf{i}}\left(\mathrm{EUR} / \mathbf{m}^{2}\right)$ & 118.8 & 124.8 & 129.2 & 136.6 \\
$n_{i}$ & 930 & 570 & 400 & 220 \\
\hline
\end{tabular}

Source: www.saie.bolognafierefiere.it $(31.12 .2011)$

Table 12: Price of leased space in category F depending on the surface for Fair II $\mathrm{n}_{0}=22000000$ $\beta=0.097$

\begin{tabular}{ccccc}
\hline $\mathbf{C}_{\mathbf{i}}\left(\mathrm{EUR} / \mathbf{m}^{2}\right)$ & 102.6 & 106.9 & 111.1 & 123.3 \\
$n_{i}$ & 1050 & 690 & 460 & 140 \\
\hline
\end{tabular}

Source: www.saie.bolognafierefiere.it $(31.12 .2011)$ 